\title{
Adiponectin concentration in the orbital fat of patients with Graves' ophthalmopathy
}

This article was published in the following Dove Press journal:

Clinical Ophthalmology

24 August 2013

Number of times this article has been viewed

\section{Uri Soiberman ${ }^{1,2}$ \\ Ran Levy',2 \\ Igal Leibovitch ${ }^{1,2}$}

'Department of Ophthalmology, Tel Aviv Medical Center, ${ }^{2}$ Sackler Faculty of Medicine, Tel Aviv University, Tel Aviv, Israel
Correspondence: Uri Soiberman Department of Ophthalmology, Tel Aviv Medical Center, 6 Weizmann Street, Tel Aviv 64239, Israel

Tel +972 36973408

Fax +97236973870

Email urisoib@gmail.com
Background: "Graves' ophthalmopathy" (GO), is an inflammatory disease of the orbit, with extensive adipose tissue involvement. Previous studies of orbital fat derived from such patients have demonstrated overexpression of the adiponectin gene and messenger RNA.

Aim: The study reported here aimed to measure the protein concentration of orbital adipose tissue adiponectin in GO patients, in comparison to healthy controls.

Methods: This was a prospective study. Orbital samples from ten healthy controls undergoing blepharoplasty and five patients with GO undergoing orbital fat decompression for proptosis were analyzed by enzyme-linked immunosorbent assay.

Results: The mean adiponectin concentration in samples from GO patients was $121.9 \pm 29.5 \mathrm{ng} / \mathrm{mL}$ (mean \pm standard deviation), versus $107.9 \pm 26.6 \mathrm{ng} / \mathrm{mL}$ in the control group $(P=0.20)$.

Conclusion: This study was unable to demonstrate a statistically significant difference in adiponectin protein concentrations between the two studied groups.

Keywords: Graves' disease, Graves' orbitopathy, ELISA

\section{Background}

"Graves' ophthalmopathy" (GO), is an inflammatory disease of the orbital connective tissue and the extraocular muscles (EOMs). The receptor for thyroidstimulating hormone is an autoantigen with a pivotal role in this type of orbital disease. ${ }^{1-3}$ The clinical presentation of GO may include exophthalmos, conjunctival chemosis, periorbital edema, or EOM dysfunction, all of which are caused by intraorbital inflammation, which is followed by the expansion of intraorbital fat and the EOMs.

The mechanism behind adipogenesis and the proliferation of orbital fat in Graves' disease is not fully understood; however, adipogenesis may be a major contributor to the development of the orbital signs seen in Graves' disease.

Adiponectin is a unique 244-amino acid protein produced by adipose tissue, mainly white adipose tissue, and is part of the adipokine family. Adipokines may have a substantial role in the regulation of immune responses and in systemic inflammatory processes. $^{4}$

Prior studies have demonstrated increased expression of the adiponectin gene and messenger RNA (mRNA) in orbital fat obtained from GO patients. ${ }^{5-6}$

To the best of our knowledge, the protein concentration of adiponectin in the orbital fat of patients with GO has not yet been examined, and it is unclear whether the overexpression of the gene and mRNA reported in other studies leads to increased 
protein production. Therefore, the study reported here aimed to assess the protein concentration of adiponectin in the orbital fat of GO patients and compare it with that of healthy subjects.

\section{Methods}

This prospective study was approved by the Institutional Review Board. All patients gave their informed consent to participate in the study. The study group included patients with GO. Orbital fat samples were obtained from these patients during orbital fat decompression. No patient had signs or symptoms of active disease, as measured by the Clinical Activity Score. The main indication for surgery was proptosis with orbital fat prolapse and dermatochalasis. Anterior extraconal fat was obtained during decompression. The control group included patients undergoing routine blepharoplasty for the treatment of dermatochalasis, with no signs or symptoms of Graves' disease or ophthalmopathy. Orbital fat was obtained from the upper medial fat pad. All participants in this study had a normal body mass index (20-25 kg/height $\left.{ }^{2}\right)$.

Orbital fat samples were immediately transferred to the laboratory, where they were divided into aliquots and frozen $\left(-80^{\circ} \mathrm{C}\right)$. Following this, the samples underwent sonication and three consecutive rounds of centrifugation - each at $13,300 \mathrm{rpm}$ for 10 minutes - to separate the fluid from the pellet.

Total protein concentration was then measured in the fluid fraction using a Pierce ${ }^{\mathrm{TM}}$ BCA Protein Assay kit (Thermo Fisher Scientific, Waltham, MA, USA). The measurement facilitated the loading of the enzyme-linked immunosorbent assay (ELISA) plate with similar amounts of total protein from each sample. ELISA of adiponectin protein was conducted in duplicate using a Quantikine ${ }^{\circledR}$ Human Total Adiponectin Immunoassay kit (R\&D Systems, Minneapolis, MN, USA) according to the manufacturer's instructions. The results were read with a Spectra MR microplate spectrophotometer (Dynex Technologies, Chantilly, VA, USA).

\section{Statistical analysis}

Statistical analysis was performed using Microsoft ${ }^{\circledR}$ Excel 2010 (Microsoft Corporation, Redmond, WA, USA). Parametric variables were analyzed using independent samples $t$-test. Results were considered statistically significant for $P$-values $\leq 0.05$.

\section{Results}

The study group comprised five females with GO who underwent surgery in our institution. The control group comprised ten patients undergoing blepharoplasty (seven females and three males). The mean age of patients in the study group was $48.8 \pm 24$ years, and $65.9 \pm 7.5$ years in the control group (means \pm standard deviation; $P=0.05$ ). Patient demographics are presented in Table 1.

The mean estimated adiponectin concentration in samples from GO patients was $121.9 \pm 29.5 \mathrm{ng} / \mathrm{mL}$ versus $107.9 \pm 26.6 \mathrm{ng} / \mathrm{mL}$ in the control group (means \pm standard deviation; $P=0.20$; Table 2 and Figure 1).

\section{Discussion}

In this study, adiponectin concentrations were only mildly elevated in the study group, but the difference did not reach a level of statistical significance.

The physiological role of adiponectin is still being investigated, as is its pathological function in Graves' disease. A previous study found elevated serum adiponectin levels in Graves' disease patients, when compared with healthy subjects. No such difference was found between patients with or without ophthalmopathy. ${ }^{7}$ These results cannot be compared with the results of the present study since the former were derived from serum, whereas the results in this study originated from orbital fat.

In another study of orbital fat from patients with severe ophthalmopathy secondary to Graves' disease, a 25-fold increase in adiponectin gene expression was detected by gene microarray when compared with orbital samples from cadavers without signs of GO. ${ }^{5}$ Another study of patients with GO found increased mRNA levels of adiponectin as well as

Table I Patient demographics

\begin{tabular}{llll}
\hline Patient & Sex & Age (years) & Surgery \\
\hline \multicolumn{2}{l}{ Study group: Graves' } & ophthalmopathy patients \\
I & Female & 28 & Orbital fat decompression \\
2 & Female & 37 & Orbital fat decompression \\
3 & Female & 80 & Orbital fat decompression \\
4 & Female & 30 & Orbital fat decompression \\
5 & Female & 69 & Orbital fat decompression \\
Control group & & \\
6 & Male & 63 & Blepharoplasty \\
7 & Female & 67 & Blepharoplasty \\
8 & Male & 79 & Blepharoplasty \\
9 & Male & 61 & Blepharoplasty \\
I0 & Female & 67 & Blepharoplasty \\
II & Female & 74 & Blepharoplasty \\
I2 & Female & 64 & Blepharoplasty \\
I3 & Female & 57 & Blepharoplasty \\
I4 & Female & 55 & Blepharoplasty \\
I5 & Female & 72 & Blepharoplasty \\
Mean & & 60.2 & \\
SD & & 16.5 & \\
\hline Ab & &
\end{tabular}

Abbreviation: SD, standard deviation. 
Table 2 Adiponectin levels in patients and controls

\begin{tabular}{lc}
\hline Patient & Estimated adiponectin level $(\mathbf{n g} / \mathbf{m L})$ \\
\hline Study group: Graves' ophthalmopathy patients \\
I & 111.1 \\
2 & 105.7 \\
3 & 168.3 \\
4 & 131.6 \\
5 & 92.7 \\
Mean & 121.9 \\
SD & 29.5 \\
Control group & \\
6 & 60.6 \\
7 & 85.3 \\
8 & 121.6 \\
9 & 144.1 \\
I0 & 131.1 \\
II & 117.0 \\
I2 & 132.2 \\
I3 & 111.7 \\
I4 & 92.8 \\
I5 & 82.6 \\
Mean & 107.9 \\
SD & 26.6 \\
\hline A & \\
\hline
\end{tabular}

Abbreviation: SD, standard deviation.

leptin - another unique adipose tissue protein. ${ }^{6}$ The present study demonstrated mild elevation in adiponectin protein concentrations in GO patients, but this was not statistically significant. There might be various reasons for the lack of a significant demonstrable difference between the control group and the GO group in this study. The makeup of control groups differs greatly among the various studies. In the present study, the control group consisted of healthy individuals who underwent elective blepharoplasty, while other studies used cadavers as controls. ${ }^{5,6}$ Additional bias may result from different levels of disease activity in the various study populations. In our present study, all GO patients were free of active orbital inflammation, and decompression was indicated for cosmetic reasons. Other studies reported that the orbital fat samples

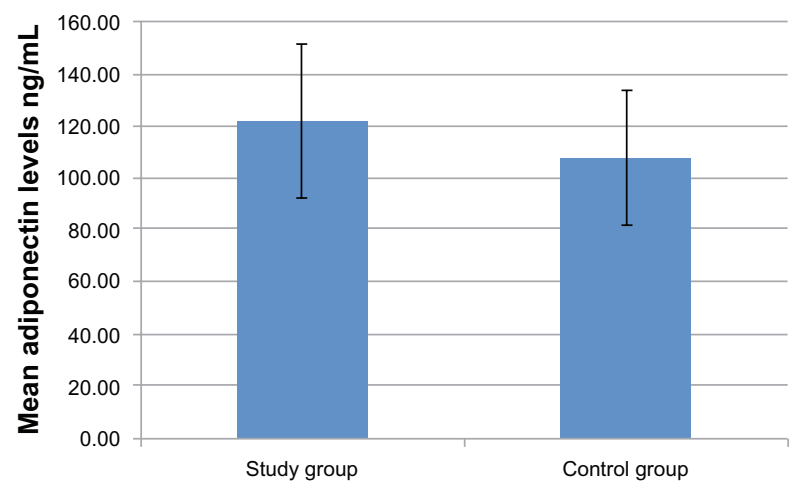

Figure I Mean adiponectin concentrations were mildly elevated in the study group in comparison to the control group. Standard deviations are depicted. were derived from patients with severe GO, however they did not specify the Clinical Activity Score at the time of sample retrieval, thereby making this another variable. ${ }^{5,6}$

The lack of a significant change in adiponectin protein concentrations may also be attributed to the source of the fat sample within the orbit. Adipose tissue samples were obtained from the upper medial fat pad in healthy controls during blepharoplasty, therefore consisted mainly of anterior orbital fat. Orbital adipose tissue samples from Graves' patients were obtained from extraconal fat during orbital decompression, so their origin was deeper within the orbit. In addition, the small size of our study group may also contribute to the lack of statistical significance in the results.

Age may have an influence on serum adiponectin concentrations, as illustrated in a study of 964 healthy subjects whose adiponectin levels increased with age. ${ }^{8}$ In the current study, the participants in the study group were younger than those in the control group by a mean of more than 15 years $(P=0.05)$. Nevertheless, adiponectin concentrations were higher in the younger GO group, so it seems that age did not bias our study results.

Further large-scale studies are required to ascertain this study's findings and to clarify the pathological and clinical significance of elevated adiponectin concentrations in Graves' ophthalmopathy patients.

\section{Disclosure}

The authors declare no conflicts of interest in this work.

\section{References}

1. Bahn RS, Dutton CM, Natt N, Joba W, Spitzweg C, Heufelder AE. Thyrotropin receptor expression in Graves' orbital adipose/connective tissues: potential autoantigen in Graves'ophthalmopathy. J Clin Endocrinol Metab. 1998;83(3):998-1002.

2. Valyasevi RW, Erickson DZ, Harteneck DA, et al. Differentiation of human orbital preadipocyte fibroblasts induces expression of functional thyrotropin receptor. J Clin Endocrinol Metab. 1999;84(7): 2557-2562.

3. Starkey KJ, Janezic A, Jones G, Jordan N, Baker G, Ludgate M. Adipose thyrotrophin receptor expression is elevated in Graves' and thyroid eye diseases ex vivo and indicates adipogenesis in progress in vivo. $J \mathrm{Mol}$ Endocrinol. 2003;30(3):369-380.

4. Krysiak R, Handzlik-Orlik G, Okopien B. The role of adipokines in connective tissue diseases. Eur J Nutr. 2012;51(5):513-528.

5. Kumar S, Leontovich A, Coenen MJ, Bahn RS. Gene expression profiling of orbital adipose tissue from patients with Graves' ophthalmopathy: a potential role for secreted frizzled-related protein-1 in orbital adipogenesis. J Clin Endocrinol Metab. 2005;90(8):4730-4735.

6. Kumar S, Coenen MJ, Scherer PE, Bahn RS. Evidence for enhanced adipogenesis in the orbits of patients with Graves' ophthalmopathy. J Clin Endocrinol Metab. 2004;89(2):930-935.

7. Sieminska L, Niedziolka D, Pillich A, et al. Serum concentrations of adiponectin and resistin in hyperthyroid Graves' disease patients. J Endocrinol Invest. 2008;31(9):745-759.

8. Isobe T, Saitoh S, Takagi S, et al. Influence of gender, age and renal function on plasma adiponectin level: the Tanno and Sobetsu study. Eur J Endocrinol. 2005;153(1):91-98. 


\section{Publish your work in this journal}

Clinical Ophthalmology is an international, peer-reviewed journal covering all subspecialties within ophthalmology. Key topics include: Optometry; Visual science; Pharmacology and drug therapy in eye diseases; Basic Sciences; Primary and Secondary eye care; Patient Safety and Quality of Care Improvements. This journal is indexed on
PubMed Central and CAS, and is the official journal of The Society of Clinical Ophthalmology (SCO). The manuscript management system is completely online and includes a very quick and fair peer-review system, which is all easy to use. Visit http://www.dovepress.com/ testimonials.php to read real quotes from published authors. 